UDK: 821.134.2.09-31 Валера X.

821.133.1.09-31 Флобер Г.

821.134.2(85).09-31 Варгас Љоса М. DOI: https://doi.org/10.18485/legado_hispanico.2020.ch7

\author{
Isidora Kalović ${ }^{1}$ \\ Doktorandkinja Univerziteta u Beogradu \\ Srbija
}

\title{
TEORIJE ROMANA HUANA VALERE, GISTAVA FLOBERA I MARIJA VARGAS LJOSE: PRILOG UPOREDNOJ ANALIZI
}

\begin{abstract}
Rezime
Ovaj rad predstavlja prilog uporednoj analizi teorijâ romana Huana Valere, Gistava Flobera i Marija Vargas Ljose. Teorije romana Huana Valere i Gistava Flobera značajne su za istraživanje zbog toga što su savremenici i što se bave probematikom romana u vreme realističkih književnih tendencija, zatim što omogućavaju uvid i poređenje španskih i francuskih teorijskih stremljenja toga doba, ali i što Valera u svojim radovima komentariše i ocenjuje rad Gistava Flobera. Budući da se Mario Vargas Ljosa u svojim esejima bavio kako teorijom romana, tako i Floberovim stvaralaštvom i poetikom, njegova poetska misao, takođe, predstavlja plodno tle za ovu uporednu analizu. Analizirajući stavove koje su navedeni pisci iznosili o romanu, zapažamo zajednička pitanja koja su obrađivali. To su odnos objektivne i stvarnosti književnog dela, pitanje forme, lepote kao cilja proznog stvaralaštva, kao i građenje likova u romanima. U ovim izdvojenim poglavljima ispitujemo sličnosti i razlike teorija koje iznose ova tri pisca po pitanju navedenih aspekata romana. Iako same teorije, pogotovo Floberova i Vargas Ljosina, otvaraju i mnoga druga pitanja pogodna za analizu, smatramo da ove četiri celine oslikavaju osnovnu, ali uvek aktuelnu teorijsku
\end{abstract}

\footnotetext{
${ }^{1}$ isidorakalovic@gmail.com
} 
problematiku romana, što ih čini najznačajnijim stubovima teorijâ koje su predmet istraživanja. Nakon poređenja, možemo zaključiti da se teorijska razmatranja Valere i Vargas Ljose najviše razilaze, dok se Floberova teorijska misao nalazi između navedenih krajnosti. On ujedno povezuje ova dva autora, zato što ga obojica u svojim radovima pominju, premda analiziraju i ocenjuju njegov rad u potpunosti drugačije.

Ključne reči: Huan Valera, Gistav Flober, Mario Vargas Ljosa, teorija romana, proces pisanja.

\section{Uvod}

U raznim rečnicima književnih termina moguće je naći određene definicije romana, poput sledećih, roman je „najvažnija epska vrsta današnjice u koju se ubrajaju razvijena prozna narativna dela slobodne kompozicije i neograničene tematike" (Gazda \& Tinecka Makovska 2015: 888) ili da je roman „jedna od osnovnih vrsta epike, duža prozna naracija (retko u stihu) od stotinu i više strana, koja sadrži radnju i pripovest, zaplete i rasplete, više različitih junaka, a odvija se kroz prostor i vreme (hronotop)“ (Popović 2007: 622-623). Ovakvi rečnici neretko pružaju i čitave preglede istorije i tipologije romana. To, međutim, ne menja činjenicu da je roman vrsta koje se teško definiše. Teorijom romana su se prvobitno bavili sami romanopisci, a kasnije i teoretičari književnosti. U zavisnosti od toga koje karakteristike su konkretno analizirali i iz koje perspektive su proučavali roman, teoretičari su izrodili raznovrsne teorije. Pisci romana XIX veka su se neretko bavili i teorijom romana, to je slučaj i sa španskim i francuskim piscima Huanom Valerom Uuan Valera) i Gistavom Floberom (Gustave Flaubert). Iako roman u Španiji ima dugu tradiciju, za razliku od francuskih teoretičara, španski teoretičari nisu dali veliki doprinos teoriji romana, niti su njihove teorije imale dalekosežan uticaj poput francuskih. S druge strane Atlantika, podatak da je prvi hispanoamerički roman nastao 1816. godine govori mnogo o zaostatku teorijske misli na hispanoameričkom tlu, čija pojava je odložena za naredni vek. Gistav Flober je, prema rečima Viktora Bromberta (1966: 19), prvi francuski pisac koji se bavi mogućnostima i tehničkim problemima, izazovima i kriterijumima romana kao umetnički značajne vrste. On je jedan od francuskih pisaca čije stvaralaštvo i poetska misao su bili predmet kritika i komentara, kao što je to slučaj sa Huanom Valerom, ali su isto tako umnogome uticali na potonje generacije 
pisaca, među kojima je i Mario Vargas Ljosa (Mario Vargas Llosa). On se bavio teorijom romana i književnog stvaralaštva kako u svojoj doktorskoj disertaciji Garsija Markes: Istorija jednog bogoubistva (García Márquez: Historia de un deicidio), tako i u brojnim esejima. Vargas Ljosa u svom eseju Neprekidna orgija: Flober i „Gospođa Bovari“ (La orgía perpetua: Flaubert $y$ «Madame Bovary») govori o Floberovoj teoriji romana i o teoriji na primeru romana Gospođa Bovari (Madame Bovary), a kao pisac pripada OY zoni hispanoameričkog novog romana, kako je naziva Elza Deenen (apud Soldatić 2002: 92), odnosno zoni „izražajnog realizma“. Dakle, Floberovu teoriju i stvaralašatvo možemo smatrati središtem, odnosno tačkom koja povezuje sva tri pisca, s tim što se Vargas Ljosa u većoj meri bavio analizom Floberovog stvaralaštva od Huana Valere, koji je posmatrao Flobera kao jednog od predstavnika aktuelnog književnog pravca.

Korpus rada čine Valerin esej $O$ prirodi i karakteru romana (De la naturaleza y carácter de la novela) iz 1864. godine, Pisma Gistava Flobera, ponajviše ona koja je posvetio Lujzi Kole (Louise Colet) u vreme petogodišnjeg rada na romanu Gospođa Bovari, i na kraju, među Vargas Ljosinim stvaralaštvom pronalazimo više značajnih teorijskih tekstova, ali rad baziramo na ranije pomenutoj doktorskoj disertaciji iz 1971. godine, zatim na eseju o Floberovoj Gospođi Bovari iz 1975. godine i u manjoj meri na memoarima Riba u vodi (El pez en el agua) iz 1993. godine. Nakon poređenja ovog korpusa, uviđamo četiri značajne celine, zastupljene kod svih autora, premda na različite načine, a to su: odnos objektivne i fiktivne stvarnosti, pitanje forme, njen značaj i način tretiranja, stil, lirizam, prozni izraz, ali i teorijska razmatranja o građenju likova u romanima.

\section{Objektivna i fiktivna stvarnost}

Sva tri pisca obrađivala su teorijski problem upliva objektivne stvarnosti u stvarnost književnog dela i veze koje između njih postoje. Kada Huan Valera govori o potrebi koju nameću aktuelni književni trendovi da delo treba da bude verodostojno, na samom početku relativizuje pojam verodostojnosti:

Para el Sr. Nocedal, por ejemplo, y para mí, que somos buenos católicos, nada hay tan verosímil como el que haga milagros un bienaventurado siervo de Dios; para un físico o un químico racionalista nada hay más absurdo: mucha parte del vulgo cree aún en los duendes, y el Sr. Nocedal y yo no creemos: los persas y los árabes creen en las hadas, en las peris 
y en los genios, y los europeos creen o han creído en las brujas: los mahometanos tienen por artículos de fe las patrañas del Korán, y los indios las encarnaciones de Brahma: Pregunto yo, ¿a cuál de estos criterios hemos de apelar para escribir una novela verosímil? (Valera 2003) ${ }^{2}$

Svet romana je, po Valerinom mišljenju, svet fantazije i na njega nije nužno primenjivati kriterijume verodostojnosti, koji su i sami relativni, jer ponekad fantastično učestvuje u stvaranju logičnog i estetski verodostojnog raspleta radnje. Svoju postavku oslikava poređenjem Don Huana kojeg je stvorio Tirso de Molina i onog čiji je tvorac Molijer. Molijerov Don Huan je verodostojniji u opštem smislu te reči, u odnosu na objektivnu stvarnost, ali su radnja i razvoj Tirsovog dela i lika dosledniji i verodostojniji u granicama samog književnog dela (Valera 2003). Tako shvaćena verodostojnost, koja se ogleda unutar samog dela, unutar stvarnosti književnog dela, koja je fiktivna, a ne podređena objektivnoj stvarnosti, dozvoljava upliv fantastike. Umetničko delo ne treba pročišćavati od neprirodnog, fantastičnog, jer je u suštini svih stvari misterija, koja je prekrivena površinskom jasnoćom i istinom. Međutim, ograđuje se Valera, elementi fantastike moraju biti uvedeni sa merom i ukusom (Valera 2003). Valera (2003) naziva roman poezijom, jer iako je pisan u prozi čini deo poetskog stvaralaštva, a osnovna razlika između istorije i poezije je što «la historia pinta las cosas como son, y la poesía como debieran ser». ${ }^{3}$ Ovako predstavljen roman, ne treba da bude ogledalo objektivne stvarnosti, već idealne, samim tim ne treba nužno da odgovara postulatima verodostojnog pripovedanja. Valera smatra da i sami realisti, među kojima nabraja i Flobera, zapravo su idealisti, jer u svojim delima stvaraju ideal, što predstavlja suštinu poezije (Valera 2003). Međutim, ideali koje Flober stvara Valera ne smatra dobrim i o tome će biti više reči u nastavku rada.

Flober, iako ne govori o fantastici, zapravo slično obrađuje vezu objektivne i stvarnosti književnog dela. Flober (2013: 89) u pismu Lujzi Kole piše: „Mene sada razdire potreba za metamorfozama. Hteo bih da sve što vidim napišem ne onakvo kakvo je, već preobraženo. Bilo bi mi

\footnotetext{
${ }^{2}$ Za gospodina Nosedala, na primer, i za mene, koji smo dobri katolici, ništa nije toliko verodostojno kao čuda blagoslovenog sluge Gospodnjeg; za jednog fizičara ili hemičara nema ničeg apsurdnijeg, veliki deo naroda još uvek veruje u patuljke, gospodin Nosedal i ja ne verujemo, Persijanci i Arapi veruju u vile, persijske vile i genije, a Evropljani veruju ili su verovali u veštice, muslimani imaju kao verske spise laži iz Kurana, Indijci inkarnacije Brame. Pitam ja, koji od ovih kriterijuma treba da primenimo da bismo napisali verodostojan roman? (prevod: autorka)

${ }^{3}$ Istorija predstvalja stvari kakve su, a poezija kakve bi trebalo da budu. (prevod: autorka)
} 
nemoguće da tačno ispričam najlepši stvarni događaj. Morao bih sa svoje strane još da kitim."

Vargas Ljosa ovu Floberovu potrebu za metamorfozom, transformacijom objektivne stvarnosti teorijski formuliše tako što tvrdi da je polazna tačka uvek objektivna stvarnost, ali ona nikada nije preslikana u delu, već je izmenjena (Vargas Ljosa 2015a: 127). On ide dalje od posmatranja odnosa između objektivne i fiktivne stvarnosti i ulazi u problematiku književnog, a i umetničkog stvaralaštva uopšte. Tvrdi da romanopisac izmišlja priče na osnovu svog ličnog iskustva, odnosno svoje lične priče i služi se beskrupulozno svime što zapaža u objekivnoj stvarnosti (Vargas Ljosa 2015a: 90). Ovu tezu je Vargas Ljosa predstavio i nekoliko godina ranije, u doktorskoj disertaciji, na primeru Garsija Markesovog stvaralaštva, kada kaže da pisac ne bira svoje teme, već da teme biraju njega i to su piščevi demoni koji mogu biti lični, istorijski i kulturni, dakle mogu poteći iz ličnog života pisca, iz istorije i društva kome pisac pripada, ili iz indirektnih izvora objektivne stvarnosti, mitologije, umetnosti ili književnosti (Vargas Ljosa 1971: 87, 94). Koji god demoni proganjali pisca, njihovo poreklo je uvek u objektivnoj stvarnosti. Kada više od dve decenije kasnije piše memoare Riba u vodi (El pez en el agua), objašnjava postupak koji upotrebljava prilikom pisanja i navodi kako je u njegovim delima stvarnost u određenoj meri prisutna tako što pođe od ličnog iskustva koje ga inspiriše, formom simulira realizam, dijalogom i opisima sa bezličnog stanovišta postigne objektivnost i na kraju pruži kritički osvrt na temu koju obrađuje (Vargas Ljosa 1993: 150). Jednu od najpoznatijih Floberovih rečenica: „Madam Bovari, to sam ja“ (Flober 2013: 146), možemo razumeti upravo u ovom kontekstu, teme i likovi romana izgrađeni su uz pomoć piščevih demona, samim tim u delu je uvek prisutan deo pisca. Valerini romani su, takođe, slika njega samog, njegov hir i fantazija, ali taj prikaz je ogledalo duše, a ne spoljašnjeg sveta (Alas Klarin 1882: 23). Sasvim suprotno od Valere, prema Vargas Ljosi, slika koju pisac ima o spoljašnjem svetu, sa kojom je najčešće u sukobu, okidač je za stvaranje romanopisca (Angvik 1987: 4). Prema tome, ono što pisac treba da obradi u romanu, treba da nude njegova slika spoljašnjeg sveta, a ne unutrašnjeg.

Dakle, ni Valera ni Flober ni Vargas Ljosa nemaju potrebu da u svojim delima preslikavaju objektivnu stvarnost, niti smatraju da delo treba da bude njen odraz. Objektivan, prema Floberu, treba da bude način pripovedanja, koji će čitaocu dozvoliti da izgradi ličnu emocionalnu senzaciju (Vargas Llosa 2004: 224). Flober i Vargas Ljosa ne negiraju da je poreklo inspiracije u objektivnoj stvarnosti i u tome se nalazi 
neraskidiva veza objektivne i stvarnosti književnog dela, koja ne definiše i ne ograničava samo književno delo, jer stvarnost koja se u njemu izgradi je uvek samo fiktivna. Valera se udaljava od ovog mišljenja tvrdeći da su fantastika i misterija prikladne za književno delo. Stvarnost romana mora biti dosledna i verodostojna samo sebi samoj i ne mora se ugledati na stvarnost koja nas okružuje. Iako Valera ubraja Flobera među realiste, pri tome ne predstavljajući to kao vrlinu, Flober govori o istinitosti ljudske mašte i o realističnom pripovedanju nečega što se nije ni dogodilo:

Prekjuče, u šumi kod Toka, na jednom krasnom mestu blizu nekog izvora, našao sam opuške od cigara ugašene mrvicama pašteta. Bili ljudi na izletu! To sam pre jedanaest godina pisao u Novembru! Tada je to bilo samo izmišljeno, a sad doživljeno. Sve što čovek izmišlja istinito je, budi uverena u to. Poezija je nešto isto tako tačno kao i geometrija. Indukcija vredi koliko i dedukcija, a zatim, kada se dođe do izvesne tačke, ne vara se više ni u čemu što se tiče duše. Moja sirota Bovari nesumnjivo pati i plače u dvadeset sela u Francuskoj odjednom, u istom času (Flober 2013: 81).

Flober smatra da nije potrebno bežati u fantastiku da bi se pobeglo od objektivne stvarnosti, dovoljno je maštati, odnosno izmišljati, a to je opet istinito, jer ono što je za nas izmišljeno, što se ne dešava nama, događa se možda drugome, na nekom drugom mestu. Slobodanka Vladiv-Glover (2010: 121) analizira transcedentalni pogled (le regard) karakterisitčan za poetiku realizma u romanu Gospođa Bovari:

Dok je ime grada fikcionalno, seoska okolina se čini kao konkretno mesto, kao okolina oko sela Croiseet (blizu Ruana), u Normandiji, gde je Flober živeo od svoje dvadeset pete godine pa sve do smrti, sa svojom majkom i nećakom. Ovaj fikcionalni ali naizgled konkretan pejzaž vizualizuje se serijom „malih slika“ koje se nižu jedna za drugom kako se oko kreće linijom horizonta kao sočivo kamere, hvatajući scenu u jednom okviru a onda krećući se glatko dalje, da bi uhvatilo sledeći kadar (frame). Stoga ono što izgleda kao opisni narativ dat sa tačke gledišta sveznajućeg naratora jeste niz slikovnih okvira, datih kroz perspektivu bezličnog oka (sočivo fotoaparata) kome se prilagođava čitaočev pogled.

Flober koristi navedenu tehniku za slikanje pejzaža, ali za njega slike nisu potvrda tačnosti, već saznajno sredstvo, jer da bismo znali, moramo videti (Izrael-Peltije 2004: 180). Valera, s druge strane, smatra da ne treba biti imitator i po uzoru na Getea, veruje da je ključ u usklađivanju podražavanja i izmišljanja, gde ono što se podražava može da predstavlja skelet ili nacrt romana, a sve ostalo treba da bude fantazija (Amoros 
2005: 53). Čini se da Valera insistira u svom teorijskom eseju na oštrijem raskidu između objektivne stvarnosti i stvarnosti romana i ne gleda pohvalno na romanopisce koji poput Flobera, a kasnije i Vargas Ljose, koji prilikom pripovedanja ostaju u zoni prikazivanja mogućeg utemeljenog na objektivnoj stvarnosti. On smatra da romaneskno treba da bude nešto što se ne dešava obično (Valera 2003). Pri tome, ne uviđa da pripovedanje mogućeg ne znači nužno preslikavanje objektivne stvarnosti, i da se stvarnost i fikcija i u ovom slučaju jasno razdvajaju. Zanimljivo je i to što Valera, kao i Flober u navedenom citatu, poredi poeziju s naukom. On smatra da svako podređivanje poezije nauci, dogmatizmu ili iznošenju nekakvih teza predstavlja unižavanje poezije (Valera 2003). Za njega cilj poezije predstavlja stvaranje lepote. Međutim, lepota je cilj i za Flobera, koji pak smatra da je poezija isto tako egzaktna kao i geometrija, odnosno nauka.

\section{Roman i forma}

Zajedničko za sva tri pisca je i isticanje značaja forme, odnosno prvenstva forme nad sadržinom romana:

Forma je i sada ono što iznad svega volim, samo kad je lepa i ništa više od toga. Žene koje imaju suviše žarko srce i odveć isključiv duh, ne shvataju tu religiju lepog, nezavisnu od osećanja. Njima je uvek potreban neki uzrok, neka svrha. A ja isto tako volim šljokice koliko i zlato. Poezija šljokica je čak viša, po tome što je tužna. Za mene postoje na svetu samo lepi stihovi, lepo sastavljene rečenice, harmonične, zvučne, lepi zalasci sunca, mesečina, slike pune boja, klasični mermerni kipovi i jako izrazite glave. Ništa izvan toga (Flober 2013: 43-44).

Flobera je više mučio problem forme od njegovog savremenika Valere, koji takođe smatra da je važniji način predstavljanja sadržine od nje same. Međutim, Vargas Ljosa (2015a: 214) smatra da je Flober svojim stvaralaštvom pokazao da je u romanu, kao i u poeziji najvažnija forma, jer ona utiče na predstavu o temi. Budući da pojam forme, koji iako je jedan od osnovnih pojmova u teoriji književnosti, može biti shvaćen na različite načine, postavlja se pitanje šta je to forma za Gistava Flobera. Vargas Ljosa (2015a: 84) smatra da:

Como en sus cartas sólo habla del «estilo», la mayoría de los críticos entiende que la obsesión formal de Flaubert tiene que ver exclusivamente con el lenguaje. En realidad, es tan acuciosa en lo que refiere a la estructura 
-el orden del relato, la organización del tiempo, la gradación de los efectos, la ocultación o exhibición de los datos- como a la escritura. Su gran aporte a la novela es al mismo tiempo técnico, tiene tanto que ver con el uso de la palabra como con la distribución de los materiales narrativos. ${ }^{4}$

Utemeljenje ove Vargas Ljosine tvrdnje pronalazimo u jednom pismu Lujzi Kole iz juna 1853. godine, kada Flober navodi da bi najviše voleo samo da piše rečenice, jer ono što ga muči je kovanje plana, upotreba efekata, „svi skriveni proračuni koji su ipak umetnost, jer utisak stila zavisi od njih, i to isključivo" (Flober 2013: 78-79). Dakle, on pod formom ne podrazumeva sam jezik, već celokupni način predstavljanja sadržine. Poznato je da je najduži i najmukotrpniji deo procesa pisanja za Flobera bilo planiranje, kojem se posvećivao veoma iscrpno i opširno, sastavljajući scenario, skice i nacrte (Vilijams 2004: 168).

Vargas Ljosa se još kao student književnosti pod uticajem Foknera bavio formom. Na privremenom poslu u službi novinara intervjuisao je brojne peruanske pisce i najviše ga je zanimalo kako oni pristupaju problemu forme. Tada je među odgovorima zapazio kako se bavljenje formom pripisuje evropskim i američkim književnostima, a ne nacionalnoj, peruanskoj, što ga je umnogome odbijalo od peruanske književnosti (Vargas Ljosa 1993: 177). Vargas Ljosini romani su najbolji dokaz značaja forme u njegovom stvaralaštvu, jer pažljiva selekcija narativnog materijala, vešto konstruisana struktura romana, poigravanje perspektivama iz kojih se pripoveda neretko privlače pažnju više negoli sama sadržina romana. On formu ističe kao suštinsku odliku dobrog govornika, jer smatra da «el buen orador puede no decir absolutamente nada, pero debe decirlo bien $»^{5}$ (Vargas Ljosa 1993: 90). To znači da je forma glavni nosilac sadržine i da od nje zavisi konačna ocena obrađene tematike i predstavljene sadržine. Ovaj Vargas Ljosin stav se preslikava i na njegovo poimanje značaja forme u okvirima književnog dela, odnosno romana.

U teorijama romana Huana Valere, Gistava Flobera i Marija Vargas Ljose pojam forme zauzima veoma važno mesto, ali kada govorimo o

\footnotetext{
${ }^{4}$ Kako u svojim pismima samo govori o „stilu“, većina kritičara smatra da je Floberova opsesija formom vezana isključivo za jezik. Zapravo je podjednako iscrpna kako u vezi sa strukturom - redosled pripovesti, organizacija vremena, gradacija efekata, skrivanje ili izlaganje podataka - tako i u vezi s pisanjem. Njegov veliki doprinos romanu je u isto vreme i tehnički, odnosi se kako na upotrebu reči, tako i na distribuciju proznog materijala. (prevod: autorka)

${ }^{5}$ Dobar govornik može da ne kaže apsolutno ništa, ali mora to da kaže dobro. (Vargas Ljosa 2015b: 198) (prevod: Ljiljana Popović Anđić)
} 
njima kao piscima, Flober je uspeo da neprekidnim radom na formi i stilu narativnu prozu izjednači s poezijom u umetničkom smislu (Vargas Ljosa 2015a: 215). To je bez sumnje bila i Valerina teorijska zamisao.

\section{Lepota kao cilj}

Već smo pomenuli da Valera i Flober smatraju da cilj književnog dela treba da bude postizanje lepote, to obojica jasno navode u svojim teorijskim tekstovima. Prema Borhesovim rečima: „Flober je bio prvi koji se posvetio stvaranju jednog čisto estetskog jezika u prozi“" (Borhes 1995: 19). Floberova pisma to potvrđuju, reč lepota je na njihovim stranicama konstanta i primetna je permanentna težnja da se stvori lep izraz i lepa rečenica. Neka pisma toliko iskreno ulaze u problematiku stvaralaštva da možemo osetiti sve muke koje je pisanje zadavalo Floberu, pogotovo ona koja su namenjena Lujzi Kole između 1852. i 1857. godine, tokom pisanja romana Gospođa Bovari. Flobera razdiru dve težnje tokom stvaralačkog procesa:

U meni su, književno govoreći, dva različita čoveka, jedan koji voli dreku, lirizam, visoke orlovske polete, sve zvučnosti fraze i njihove ideje; i drugi, koji kopa i traži istinu koliko god može, koji voli da sitnu činjenicu istakne jednako snažno kao i krupnu, koji bi želeo da ljudi skoro materijalno osete stvari koje on predstavlja, taj voli da se nasmeje i rado se bavi životinjskim crtama čoveka (Flober 2013: 62-63).

U ovom drugom tipu pisca koji Flober opisuje, nalazi se još jedan važan pojam za teoriju romana Vargas Ljose, a to je totalizacija (totalización) ili totalni roman (novela total), stvaranje stvarnosti književnog dela koja je toliko sveobuhvatna i široka kao i sama objektivna stvarnost (Vargas Ljosa 2015a: 132). Totalni karakter romana se ogleda u tri aspekta - totalnoj materiji, totalnoj formi i narativnoj strategiji. $\mathrm{Na}$ primeru dela Sto godina samoće vidimo da se totalna materija odnosi upravo na ovu sveobuhvatnost sadržine, koju Vargas Ljosa zapaža i kod Flobera, dok totalna forma podrazumeva neponovljivost i samodovoljnost koje se postižu neraskidivom vezom između materije i strukture (Vargas Ljosa 1971: 480). Prvi tip pisca koji se nadmeće u Floberu je lirski pisac, odnosno romanopisac i na osnovu stava koji Valera, Flober i Vargas Ljosa imaju o lirizmu u romanesknoj formi možemo porediti njihove teorije. Samim tim što Valera roman naziva poezijom, insistira na formi i predstavljanju lepog, jasno je da lirizam u njegovoj teoriji romana zauzima 
veoma važno mesto. S druge strane, on odbacuje potrebu za prikazivanjem mogućeg i realističnog, što znači da njegova teorija predstavlja jednu krajnost. Gistav Flober se bori sa svojim lirskim i realističnim porivima, ali lirizam, stil i lepota izraza definišu njegovo stvaralaštvo. Lepota za Flobera nije u sadržaju već u obradi i prezentaciji istog i na tom polju je njegov originalni doprinos najveći. On se, između ostalog, ogleda i u upotrebi određenih gramatičkih oblika, interpunkcijskih znakova i poigravanja jezikom uopšte, koje nije uvek ni moguće prevesti na druge jezike (Finč 2004: 178-151). U spoju koji ga toliko muči, kao pisac bio je mnogo uspešniji od svog savremenika Valere, koji često nije primenjivao svoja teorijska zapažanja u delima (Karanović 2012: 221). Vargas Ljosa bi na osnovu ove kategorizacije bio druga krajnost u odnosu na Valeru, jer lirizmu kako u teoriji, tako i u svojim romanima ne posvećuje naročito pažnju. On se mnogo više bazira na ovom drugom tipu Floberovog pisca, koji se trudi da stvori totalnu stvarnost.

U prethodnom poglavlju smo govorili samo o formi, zbog toga što je ne izjednačavamo isključivo sa stilom i jezikom. Primera radi, vidimo da je u slučaju Vargas Ljose forma izuzetno važna, i to onaj deo koji se tiče strukture, perspektive, redosleda predstavljanja pripovednih tokova, dok stil, zvučnost i lepota izraza to nisu. Vargas Ljosa stil posmatra kao sredstvo pomoću kojeg pisac transformiše demone u stvarnost književnog dela (Vargas Ljosa 2015a: 128). Gistav Flober, kao što smo već pokazali, takođe se bavi strukturom i takozvanim „kovanjem planova“, ali ponajviše stilom i lepotom izraza. U nastavku poglavlja ćemo predstaviti Floberova razmatranja o lirizmu, stilu i lepoti izraza u prozi, budući da su kod njega zastupljenija nego kod Valere i Vargas Ljose:

Poezija nikako nije slabost duha, a te nervozne osetljivosti to jesu. Ta sklonost da se prekomerno oseća je slabost. [...] Isto je u književnosti. Strast ne pravi stihove, i što god ste ličniji, bićete slabiji. [...] Što manje čovek ima osećanja za nešto, utoliko je sposobniji da to izrazi onakvo kakvo je (kakvo je uvek, samo po sebi, u svojoj opštosti i oslobođeno svih prolaznih slučajnosti). Ali treba imati sposobnosti pa to učiniti sebi osetnim. Ta sposobnost nije ništa drugo nego genijalnost: videti, imati pred sobom model koji sedi (Flober 2013: 74-75).

Flober teži pronalaženju adekvatnog stila i načina pripovedanja kako bi jedna tema mogla da se oseti, što je značajna razlika u odnosu na pisce romantizma koji su smatrali da treba osetiti temu kako bi bila dobro prikazana (Vargas Ljosa 2015a: 219). Kada govori o stilu i izrazu, Flober ne razlikuje prozu od poezije: 
Kakva je pasja stvar ta proza! Nikad to nije gotovo; uvek ostaje da se nešto preradi. Ja ipak mislim da joj se može dati čvrstina stiha. Dobra prozna rečenica treba da bude kao dobar stih, neizmenljiva, isto tako ritmična, isto tako zvučna.[...] Više razmišljaj pre nego što pišeš i posveti se reči. Sav dar pisanja, na kraju krajeva, sastoji se u izboru reči. Tačnost izraza čini snagu. Sa stilom je isto kao i sa muzikom: ono što je najlepše je i najređe, a to je čistota zvuka (Flober 2013: 75-76).

Flober stremi perfektnom stilu, to je iz pisama sasvim jasno, kritički okrenut prema sebi žali što ne može da dostigne stil kakav zamišlja (Flober 2013: 62). 0 značaju stila za roman govori sa sličnog stanovišta kao Valera. Mašta o tome da napiše delo sa što manje sižea, koje bi nosila sama snaga stila, jer „najlepša dela su ona u kojima ima najmanje sadržaja; što god je izraz bliže misli, što god se reč više priljubi i nestane, utoliko je sve lepše" (Flober 2013: 63). Dve decenije nakon objavljivanja romana Gospođa Bovari, u pismu Žorž Sandovoj odbacuje da postoji „njegova škola“, njegovi sledbenici, iako je pre svega zbog odabira tema uticao na pisce naturalizma, jer kako kaže „iznad svega tražim lepotu, za kojom su moji drugovi prilično malo u potrazi“ (Flober 2013: 137). Stoga možemo da zaključimo da su za Flobera stil i lepota proznog izraza bili vrhunac kome je težio, a to je slučaj i sa Valerom i njegovim teorijskim esejima. Zbog čega je onda Valera tako malo cenio Flobera? Čini se da kada govori o njemu predstavlja samo jednu stranu Floberovog stvaralaštva, a to je realizam kome se on teorijski suprotstavlja. Pored toga, ovakav Valerin stav može biti takav pošto Flober ne prečišćava svoje romane od ružnog, dok on smatra da treba prikazavati lepo u delima. Likovi koje Flober stvara nisu ideali kakvi bi, prema Valeri, trebalo da budu. Valera u potpunosti zanemaruje pitanje forme, lirizma, stila i lepote izraza kojima se Flober toliko bavio a, između ostalog, imao gotovo podudarne stavove sa španskim savremenikom. Kada je reč o romanima, Flober je umešnije razradio određene Valerine teorijske postavke, negoli sam Valera.

\section{Romaneskni likovi}

Huan Valera u svom eseju (Valera 2013) govori o slobodnoj volji (libre albedrío) likova i smatra da je poetičnije i da više priliči romanu da lik predstavlja sopstvenu volju, a ne volju nekog drugog. Pored toga, pisac može da predstavi jednog prostog, gnusnog lika, ali mora da postoji njegova suprotnost koja će predstavljati ideal čistote i savršenstva, da bi se na taj način prečistila umetnička slika (Valera 2003). Važnije od 
samog predstavljanja postupaka i spoljašnjosti likova jeste predstavljanje duše lika, onog najintimnijeg u njemu. Jedino što ga istinski zanima je unutrašnji svet (Amoros 2005: 37). Prilikom građenja istorijskih likova nije lako verodostojno prikazati jednu istorijsku ličnost, jer bi trebalo da postoji istorija koja prikazuje ličnosti na samo jedan pouzdan način (Valera 2003). Kao romanopisac, Valera se pretežno bavi ženskom psihologijom, predstavlja dušu svojih protagonista i svet viđen njihovim očima (Karanović 2012: 221).

Flober uviđa da likovi moraju delom biti izgrađeni na osnovu iskustva i onoga što je autor doživeo, s tim što je bolje da romanopisac raseje sebe kroz likove i time stvori mnoštvo različitih karaktera (Lojd 2004: 76). On za razliku od Valere, u svojim likovima oslikava i ono što Valera smatra neukusnim i ružnim. Pored toga, govori i o predstavljanju suprotnih ličnosti, ali ne da bi se prikazao ideal čistote i lepote kao u Valerinom slučaju, već da bi likovi isticali osobine jedni drugih: „Taj Žilov karakter je jasno osvetljen samo zbog kontrasta sa Anrijevim. Izdvojena, jedna od te dve ličnosti bila bi slaba. Ja sam prvo zamislio samo Anrija. Potreba za suprotnim što ga ističe navela me da zamislim Žila" (Flober 2013: 62). Flober se u svojoj prepisci dotakao problema predstavljanja istorijskih likova u romanu, smatrajući da oni moraju biti pažljivo uvedeni jer budući da su zanimljiviji nego fiktivni likovi, lako mogu da postanu centralni. On se s ovim problemom obračunao tako što istorijske likove predstavlja isključivo u pozadini (Grin 2004: 97-98). Floberov najveći doprinos, smatra Porter (2004: 122) je u stvaranju veoma raznolikih dramskih likova i oslikavanju groteskno smešnog.

Vargas Ljosa primećuje Floberovu tendenciju da ljude i likove predstavi poput stvari, na primer u fragmentarnom opisivanju delova tela. Na taj način likovi gube individualnost, predstavljeni su uopšteno, kao industrijski proizvodi istog kalupa. S druge strane, Floberov deskriptivni metod i slobodni indirektni stil omogućavaju direktan uvid u život uma i subjektivnost lika (Vargas Ljosa 2015: 135, 219). Leopoldo Alas Klarin npr. smatra da Flober uspešno predstavlja zapažanja autora kao razmišljanja samih likova i na taj način se stiče utisak kao da se pripoveda iz unutrašnjosti lika (Sobejano 2009). U tome se ogleda još jedan veliki Floberov doprinos modernim tendencijama romana.

Likovi koje gradi Vargas Ljosa, kao i teme, preuzeti su iz objektivne stvarnosti. Na primer, likovi romana Grad i psi su ili veoma slobodni i transformisani stvarni modeli, iz vremena kada je pisac pohađao vojnu školu „Leonsio Prado“, ili izmaštani (Vargas Ljosa 1993: 57). Vargas Ljosa, kao i Flober, nalazi inspiraciju za svoje likove u objektivnoj stvarnosti. 
Nakon poređenja Vargas Ljosinih memoara i romana, zapažamo brojne sličnosti s romanesknim likovima koje je stvorio i s ličnim iskustvima koja je doživeo. Flober se, s druge strane, inspiriše tako što analitički opaža stvarnost oko sebe i tipove ličnosti.

\section{Zaključak}

Floberova teorijska razmišljanja o romanu, rasuta po njegovoj obimnoj prepisci, bave se gotovo svim sferama ove književne vrste, ističući istinu i lepotu kao najvažnije ciljeve romana. Pisac, prema Floberu, treba da piše hladne glave i mirnog srca, jer je postizanje lepote izraza i stila gotovo rudarski posao, pri tome se nikada ne gubi iz vida tačnost izraza i važnost zadatka da se pronađe prava reč, reč koja pogađa suštinu, odnosno samu istinu. Istina i lepota su dve strane istog novčića, one su cilj, i u tom pogledu tematika može biti svakojaka, a ne nužno čista, lepa i uzorna.

Esej Huana Valere predstavlja odgovor, alternativu trendovima u španskoj književnosti druge polovine XIX veka. On ovom prilikom izlaže svoju idealističku teoriju romana (Karanović 2012: 221) kao protivtežu realističkim i naturalističkim stremljenjima u romanu epohe. Međutim, u osnaživanju argumenata protiv ovih težnji u španskoj književnosti gubi iz vida brojne mogućnosti i sužava, pa čak i pojednostavljuje pogled na celokupnu problematiku. Lepota je i za Valeru cilj, ali se ogleda prvenstveno u prikazivanju lepog. Iako je i Flober mrzeo što ga nazivaju realistom (Brombert 1966: 3), Valera ga ocenjuje samo na osnovu realističnog pripovedanja i odabira tema koje smatra vulgarnim, trivijalnim, ružnim, ne sagledavajući uopšte mogućnost sinteze trivijalne teme i realističnog pripovedanja, s jedne strane, i prefinjenog stila, lirizma i lepote izraza, $s$ druge strane. Tačno je, Flober prikazuje i ono ružno, ali čini to na lep način, kroz izraz koji mukotrpnim radom usavršava i glanca do perfektnosti, kojom i dalje ne biva zadovoljan. Čini se da ovaj drugi deo Valera ne uviđa ili ga jednostavno ne ističe kada je u pitanju Floberovo stvaralaštvo.

Vargas Ljosa kao čitalac Valere i Flobera i savremeni hispanoamerički pisac, sa distancom posmatra teorijske tokove kojima su pripadala ova dva pisca. Zato se i njegov pristup veoma razlikuje od Valerinog i Floberovog. On u svojim teorijskim tekstovima, više nego o samoj teoriji romana, govori o procesu stvaranja narativne proze, na primerima konkretnih autora ili dela. Zbog toga je u njegovim tekstovima uvek prisutno pitanje polazišta i porekla inspiracije prilikom književnog stvaralaštva, a njegov stav je da je to polazište u objektivnoj stvarnosti koja okružuje pisca. 
Nakon poređenja, možemo zaključiti da se teorijska razmatranja Valere i Vargas Ljose o uplivu objektivne stvarnosti u fiktivnu stvarnost romana, lirizmu i tematici koja treba da bude predmet romana najviše razilaze, dok se Floberova poetska misao nalazi između dve krajnosti. On povezuje Valeru i Vargas Ljosu, tako što je njegovo stvaralaštvo predmet njihovih eseja, u kojima ga analiziraju i ocenjuju u potpunosti drugačije.

\section{BIBLIOGRAFIJA}

Alas Klarin 2003 [1882]: Leopoldo Alas Clarín. «Del estilo en la novela». Arte y letras, 3: 23-24. Web. 10/11/2019.

Amoros 2005: Andrés Amorós. La obra literaria de don Juan Valera: la «música de la vida». Madrid: Castalia.

Angvik 1987: Birger Angvik. «Mario Vargas Llosa's Theory of the Novel and Its Application in Criticism». Iberoamericana - Nordic Journal of Latin American and Caribbean Studies. 17/1-2: 3-26. Web. $01 / 11 / 2019$.

Borhes 1995: Horhe Luis Borhes. Ogledalo zagonetki: eseji o književnosti. priredio Radivoje Konstantinović. Novi Sad: Svetovi.

Brombert 1966: Victor Brombert. Novels of Flaubert. A Study of Themes and Techniques. Princeton: University Press.

Finč 2004: Alison Finch. «The stylistic achievements of Flaubert's fiction». Thimoty Unwin (ed.). The Cambridge companion to Flaubert. Cambridge: University press, 145-164.

Flober 2011: Gistav Flober. Pisma. Beograd: LOM.

Gazda \& Tinecka Makovska 2015: Gžegož Gazda \& Slovinja Tinecka Makovska. „Roman“. Rečnik književnih rodova i vrsta. Beograd: Službeni glasnik, 888-897.

Grin 2004: Anne Green. «History an its representation». Thimoty Unwin (ed.). The Cambridge companion to Flaubert. Cambridge: University press, 85-104.

Izrael-Peltije 2004: Aimée Israel-Pelletier. «Flaubert and the visual». Thimoty Unwin (ed.). The Cambridge companion to Flaubert. Cambridge: University press, 180-195.

Karanović 2012: Владимир Карановић. „Теорија романа Хуана Валере“. Маја Анђелковић (ур.). Савремена проучавања језика и књижевности (Зборник радова са III научног скупа младих филолога Србије одржаног 12. марта 2011. године на 
Филолошко-уметничком факултету у Крагујевцу), Година III, књига 2. Крагујевац: ФИЛУМ, 219-227.

Lojd 2004: Rosemary Lloyd. «Flaubert's correspondance». Thimoty Unwin (ed.). The Cambridge companion to Flaubert. Cambridge: University press, 67-84.

Popović 2007: Tanja Popović. „Roman“. Rečnik književnih termina. Beograd: Logos Art, 622-626.

Porter 2004: Laurence Porter. «The art of characterisation in Flaubert's fiction». Thimoty Unwin (ed.). The Cambridge companion to Flaubert. Cambridge: University press, 122-144.

Sobehano 1981: Gonzalo Sobejano. «De Flaubert...a Clarín». Quimera: revista de literatura, 5: 25-29. Web. 30/09/2019.

Soldatić 2002: Dalibor Soldatić. Prilozi za teoriju novog hispanoameričkog romana. Beograd: Filološki fakultet / Kragujevac: Nova svetlost.

Valera 2003 [1864]: Juan Valera. «De la naturaleza y carácter de la novela». Estudios críticos sobre literatura, política y costumbres de nuestros días. Tomo I. Madrid: Librerías de A. Durán, 218-254. Web. 30/09/2019.

Vargas Ljosa 1971: Mario Vargas Llosa. García Márquez: historia de un deicidio. Barcelona: Seix Barral.

Vargas Ljosa 1993: Mario Vargas Llosa. El pez en el agua. Barcelona: Seix Barral.

Vargas Ljosa 2004: Mario Vargas Llosa. «Flaubert our contemporary». Thimoty Unwin (ed.). The Cambridge companion to Flaubert. Cambridge: University press, 220-224.

Vargas Ljosa 2015a: Mario Vargas Llosa. La orgía perpetua. Barcelona: Debolsillo.

Vargas Ljosa 2015b: Mario Vargas Ljosa. Riba u vodi. Prevela Ljiljana Popović Anđić, Beograd: Laguna.

Vilijams 2004: Tony Williams. «The writing process: scenarios, sketches an rough drafts». Thimoty Unwin (ed.). The Cambridge companion to Flaubert. Cambridge: University press, 165-179.

Vladiv-Glover 2010: Slobodanka Vladiv-Glover. Poetika realizma. Pančevo: Mali Nemo. 


\title{
THEORIES OF THE NOVEL OF JUAN VALERA, GUSTAVE FLAUBERT AND MARIO VARGAS LLOSA: A COMPARATIVE ANALYSIS
}

\begin{abstract}
Summary
This paper represents a comparative analysis of the theories of the novels of Juan Valera, Gustave Flaubert and Maria Vargas Llosa. The theories of the novels of Juan Valera and Gustav Flaubert are important for the research because they are contemporaries and deal with the problematics of novels in times of realistic literary tendencies, then they allow the insight and comparison of Spanish and French theoretical aspirations of the time, but also that Valera in his works comments and evaluates the work of Gustave Flaubert. Since Mario Vargas Llosa has dealt with both the theory of the novel and Flaubert's work and poetics in his essays, his poetic thought also forms a fertile ground for this comparative analysis. Analyzing the views expressed by these writers about the novel, we note the common issues they addressed. These are the relationship between the objective and fictional reality of the literary work, the question of form, beauty as the goal of prose creation, and the construction of characters in novels. In these separate chapters, we examine the similarities and differences of the theories presented by these three writers with respect to the aforementioned aspects of the novel. Although the theories themselves, especially Flaubert's and Vargas Llosa's, open up many other questions that are amenable to analysis, we find that these four sections reflect the basic, but always current theoretical problems of the novels, making them the most important pillars of the theories under study. After comparing, we can conclude that the theoretical considerations of Valera and Vargas Llosadiverge the most, while Flaubert's theoretical thought is between the mentioned extremes. He also connects the two authors, because they both mention him in their works, but analyze and evaluate his work completely differently.
\end{abstract}

Keywords: Juan Valera, Gustave Flaubert, Mario Vargas Llosa, theory of the novel, writing. 